\title{
Attitudes Towards Statistics in Secondary Education: Findings from fsQCA
}

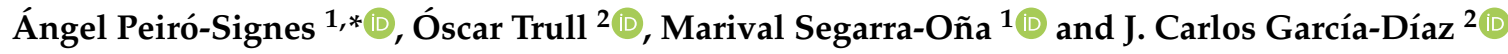 \\ 1 Management Department, Universitat Politècnica de València, 46022 Valencia, Spain; maseo@omp.upv.es \\ 2 Department of Applied Statistics and Operational Research and Quality, Universitat Politècnica de València, \\ 46022 Valencia, Spain; otrull@eio.upv.es (Ó.T.); juagardi@eio.upv.es (J.C.G.-D.) \\ * Correspondence: anpeisig@omp.upv.es
}

Received: 7 April 2020; Accepted: 8 May 2020; Published: 16 May 2020

check for updates

\begin{abstract}
Students report a high degree of anxiety and reduced self-confidence when facing statistical subjects, especially in secondary education. This anxiety turns into poor academic performance. Most studies have used linear models for studying the interrelation between different attitudes and proving their impact on performance or related variables. This study uses a different approach to explain and better understand the causal patterns of factors stimulating lower levels of anxiety in students when facing statistics in secondary education. We employed the Multi-factorial Scale of Attitudes Toward Statistics (MSATS) and fuzzy-set qualitative comparative analysis (fsQCA) on a sample of 95 secondary school students in Spain. We identified the recipes or causal combination of factors, leading to low and high levels of anxiety. The results indicate that self-confidence and motivation are important factors in these recipes, but there is no single necessary condition that ensures lower levels of anxiety.
\end{abstract}

Keywords: statistics; attitudes; anxiety; self-confidence; motivation; fsQCA

\section{Introduction}

It is common for many students to struggle when dealing with mathematics and mathematical related subjects, such as statistics. These troubles are often due to negative attitudes, which are major obstacle for effective learning [1]. Although the factors that are relevant in students' performance in statistics have received much attention [2,3], there is still a need to build on new knowledge regarding attitudes towards statistics [4].

Attitudes consist of emotions and behavioural patterns [5]. Gal et al. [6] describe attitudes as "stable intense feelings that develop as repeated emotional responses and automatized over time". It is important to distinguish between attitudes and beliefs. The latter refers to momentary emotions due to immediate experiences.

Attitudes are a good predictor of content assimilation, its use, the motivation for learning and of performance [7], and they are crucial for the right learning atmosphere surrounding statistics [8]. They can be positive ("statistics will be needed in my future job") or negative ("no application can be obtained from statistics in my [future] work"). Such attitudes may affect the extent to which students will develop and apply statistical skills [6] and, therefore, their academic achievement. Attitudes in the learning process are not directly observable [8,9]. Although researchers agree that these attitudes are comprised of several dimensions, there is no consensus regarding the number and their relevance $[8,10]$. Several studies have focused on determining these dimensions in attitudes towards mathematics [11] and, more specifically, statistics. 
Researchers have developed questionnaires that are focused on uncovering the underlying structures of components that condition attitudes towards statistics. However, these studies do not fully agree about which factors should be considered and how are they operationalized.

Starting with the Statistics Attitude Survey (SAS) that was developed by Roberts and Bilderback [12], there have been many assessment instruments to evaluate attitudes towards statistics. Among the different instruments, the Attitudes Toward Statistics Scale (ATS) [13] and the Survey of Attitudes Toward Statistics Scale (SATS) [14] are the two most widely used. ATS measures students' attitudes towards the use of statistics in their field of study and towards the statistics courses in which they are enrolled. SATS measures feelings regarding statistics through the Affect scale, the Cognitive Competence scale, the Value scale, and the Difficulty scale. Affect measures positive and negative feelings concerning statistics; Cognitive Competence measures the attitudes regarding intellectual knowledge and skills when applied to statistics; Value measures the attitudes about the usefulness, relevance, and worth of statistics in personal and professional life; and finally, Difficulty measures the attitudes about the difficulty of statistics as a subject.

Instruments to measure these attitudes have also been developed for Spain, among which we can highlight those by Auzmendi [9], Estrada [8], and Bayot et al. [15]. However, Auzmendi's instrument [7] is the most extensively used in Spain [16]. According to Auzmendi [9] and other authors [17] attitude towards statistics has three basic dimensions: the Cognitive dimension, or relationship with thinking, conceptions, and beliefs about statistics; the Affective or emotional dimension, made up of positive or negative emotions and feelings that statistics evoke and the Behavioral dimension, linked to actions or intentions in relation to the statistics. All of these instruments have components that nearly overlap in what they represent. For example, Auzmendi [7] found a correlation of 0.86 between her instrument and SAS. Additionally, we can see that the Cognitive Competence component in SATS [18] represents attitudes regarding intellectual knowledge and skills when applied to statistics, which is equivalent to Self-Confidence in Auzmendi [9]; similarly, Value corresponds to Usefulness, Interest to Motivation, or Affect to Enjoyment.

Most of these factors and their relation to students' performance are supported by different theories, such as Expectancy-Value Theory, Self-efficacy Theory, Self-determination Theory, or Achievement Goal Theory. Eccles's Expectancy Value Theory [19] suggests that students' expectations of how well they will do on a task (self-confidence) and the task's perceived value (usefulness) are related and will impact performance. Similarly, Self-efficacy Theory claims that students who have positive perception of their capabilities are more likely to perform better [20]. Self-determination Theory adds to the latter and suggests that feelings about statistics (Affect) are influencers of students' learning. Finally, Achievement Goal Theory focuses on Value and Effort to achieve the goal as drivers of the behaviour in a particular subject.

Studies of attitude towards statistics also explored other variables that were not related to the student behavior, such as age [21-23], gender [17,21,24], or the teaching methodology [25-30]. The studies, including sex and age, led to different and contradictory results. On the other hand, changing the teaching methodology to a more practical and participatory one seems to improve attitude and performance and reduce the anxiety towards statistics $[25,26,31]$.

\subsection{Relation between Attitudes, Anxiety and Performance}

Anxiety is usually thought of as emotional fear or apprehension towards that object, as a reaction to a situation [22,32]. Many authors [6,10,23,33-39] conclude that statistical courses and specially statistical exams increase the degree of anxiety in students and result in inadequate academic performance. Fitzgerald et al. [40] added expectations to anxiety as the best predictors of student performance in the statistics course.

The relationship between anxiety and performance has been widely studied in education [41-45] and in the learning of statistics [35,39,46-50]. Chiesi and Primi [35] have reported differences in these studies with respect to how attitudes, anxiety, and performance relate, particularly in terms 
of their importance and significance. Some authors $[35,48,50,51]$ reported that the relation between anxiety and performance was not significant. On the contrary, the studies from Onwuegbuzie [52,53], Onwuegbuzie \& Seaman [38], Tremblay et al. [39], or Zeidner [22] confirmed that it was significant. For example, the study of Lalonde and Gardner's [50] showed that attitudes and anxiety influenced performance through the mediation of motivation. The replication of the study by Tremblay's et al. [39] study found that anxiety also affected the performance directly. Moreover, they found that negative attitudes towards the subject increased the levels of anxiety and consequently reduced the achievement.

The differences in how anxiety relates to performance and its significance might be related to several elements, such the variety of the models tested [10], the administration time of the survey, the context, the different predictors accounted for in the study, or the research methodology, which assumes linear and symmetric relationships between the variables of interest. However, we can still infer from these studies that the reduction of students' anxiety can translate into better academic performance directly or through an improvement in attitudes towards statistics. Therefore, we can expect some of these factors (e.g., self-confidence, usefulness, motivation) to be potential elements that are present in causal combinations positively affecting (reducing) students' level of anxiety towards statistics, which eventually has a direct relationship with the students' performance in the subject.

Attitudes are usually understood as evaluative reactions to an object, and the antecedent or the manifestation can be in terms of emotions, cognitions, or behaviours [10]. Similarly to the anxiety-performance relation, research has been conducted $[7,13,21,54-56]$ studying the relationship between the attitude towards statistics and academic results, because attitudes are considered to have an important influence in the teaching and learning processes [29]. Sorge \& Schau [57] and Wisenbaker et al. [58] described a positive effect of attitudes on performance. In Spain, studies, such as [9,17,59], uncovered the existence of a positive correlation between student attitudes and their performance in statistics.

\subsection{Predictors of Attitudes and Anxiety}

Carmona [10] classified the predictors of attitudes toward statistics in two groups: those that relate to the previous experience of the students in the area and the self-beliefs (self-confidence, expectations and self-efficacy) related to the subject. Expectations are a manifestation of self-efficacy $[60,61]$. Additionally, both expectations and the task value are motivators to perform achievement tasks [14]. According to [14], students' expectations depend on the self-confidence and the perception of the task demand. The task value, on the other hand, is determined by the importance of doing well on a task (attainment value), the interest and enjoyment gained from doing the task (intrinsic value), the usefulness (utility value), and the effort (costs) [19].

Self-perception has been negatively related to anxiety [22], and positively linked to attitudes [33,62-64]. Low self-perception and lack of self-confidence about their statistics skills is a major threat to students' performance [65]. Moreover, Students' interpretation of previous experiences in similar courses has also been reported as the most influential source of their self-efficacy [66]. Subsequently, self-perception and, therefore, self-confidence are been built on previous experiences in the area. The previous knowledge [1], previous experience in the learning context [35], or the links of statistics to mathematics [67] affect students' attitudes towards statistics and student performance. In fact, Ramirez et al. [68] review of the literature on previous research regarding these elements highlighted that 15 out of 17 studies found significant and positive relationships among attitude components and achievement. Additionally, all six studies relating experience and prior success reported a positive and significant relation to performance in statistics courses.

Thus, students' attitudes and anxiety have persistently related to the previous training in mathematics and statistics and with the self-concept about the skills that were related to these subjects [10].

Some studies have considered the motivational approach. Auzmendi [9] and Budé et al. [51] found that the affect towards the subject affects performance. Moreover, we can see in these studies 
motivational dimensions that partially overlap with some dimensions of attitude towards statistics. Learning approaches have been also a matter of discussion in this field. Daley and Onwuegbuzie [69] found less anxiety in students that were oriented to more to logical and mathematical thinking. Mondéjar et al. [28] found more anxiety in superficial learners when compared to deep learners. Onwuegbuzie and Daley [32] and Walsh and Ugumba-Agwunobi [70] concluded that students' perfectionism, which is a representation of the expectations about their own performance, leads to higher levels of anxiety.

Statistics is necessary for many university degrees [29], especially at technical universities, and presents specific didactic problems, because students have a very heterogeneous mathematical base [71]. In secondary school of many European countries, statistics is present within compulsory secondary education curricula as a part of mathematics. Subsequently, to improve student's performance in higher education courses, research points towards a change in student attitudes in the early stages of their relationship to the discipline. Positive attitudes towards statistics are related to positive past experiences in statistics or in mathematics, which many times are formed in secondary education. In other words, building positive attitudes in lower levels of education might improve student attitudes and results in statistics or statistical methods in higher levels of education.

Determining what factors condition student attitudes towards statistics is important, but how these attitudes affect the levels of anxiety and student performance, is also of interest. The educator might design strategies to modify these attitudes and improve student performance. Indeed, how educators organize teaching and learning activities reinforces certain attitudes in students [72-74]. Efforts have been made to update the teaching methodology to use more challenging and student-oriented activities that students can apply, would allow them to experience statistical concepts [75-80] and might change their beliefs about and attitudes towards statistics [81].

This literature review suggests that the relationships between factors that are related to statistics achievement are quite complex. However, that there is still a need for deeper knowledge about the relationship between attitudes and anxiety level to encourage improved student performance in statistics. The methodological approach of this study avoids some of the issues mentioned in the next section to gain a complementary approach to the existing knowledge. Thus, we are looking to uncover which combination or combinations of attitudes towards statistics (conditions) decrease students' anxiety towards statistics (desired output). We sought to determine how enjoyment, usefulness, motivation, and confidence affect anxiety.

\section{Materials and Methods}

Researchers have used different quantitative techniques to explain and model the complex relationships between different factors that affect attitudes towards statistics and student performance [82]. These studies normally look for potential predictors of attitudes towards statistics, their interrelationships, and student performance. In addition to the use of different variables and measurement instruments, these studies also vary in terms of methodology and how the variables are related. They sometimes include additional variables that may act as moderators in the models, such as gender [47,83], mathematical background or competence [9,35,46,84], general learning ability [85], learning approach [28], or teaching method [30]. Most studies have followed linear data analysis approaches, such as regression or structural equation modelling. Unlike these methods, configurational comparative methods, such as fuzzy-set qualitative comparative analysis (fsQCA), look for causal recipes - that is, a combination of conditions that causes a desired outcome [86].

Linear methods look for the net effect that one or more (independent) variables cause on another (dependent) variable - that is, whether each independent alone significantly impacts the dependent variable. However, the impact of an independent variable and its significance might change depending on the other independent variables included in the model [87]. Therefore, we are estimating the average effect of the variables of interest in the desired outcome. Put simply, in linear methods, 
independent variables are competing to explain variance of the dependent variable and, in fsQCA, they cooperate to create the outcome [88].

In regression-based studies, combinations of conditions are analysed through analysis of their interaction. Interpretation can become complicated as the number of involved variables increases [89]. Within fsQCA, we can study different paths or combinations of causal conditions, resulting in an outcome or final state [90] and can thus examine complex combinations of causal conditions that normally are interdependent or that act differently, depending on context [91]. The latter-asymmetry-contrasts with linear models, in which the relationship between the outcome and predictors is assumed to be symmetric. Thus, the configurations that bring about high levels of the outcome might be different than the configurations resulting in low levels.

FsQCA deals with some of these limitations shown in regression-based models, such as symmetry or the lack of proficiency at handling multi-faceted interdependencies between variables [92]. Additionally, fsQCA was developed and it has been used for small or medium data samples [93]. However, it has been widely used in large- $\mathrm{N}$ data in the social sciences, and it is applicable to research using survey data [94]. Thus, this method is ideal as a complement to the regression based studies [95] that have been reported so far.

In this study, we take this new approach to the problem [92] and look for combinations of conditions that are sufficient for or necessary to have a positive or negative influence on the level of student anxiety towards statistics. We used the Multi-factorial Scale of Attitudes Toward Statistics (MSATS) [9] in a sample of 95 students from the same secondary school. The students who completed the questionnaire were in the two levels (Compulsory Secondary Education and Baaccalaureate) prior to the first university course, and the three different grades had mathematics with statistics that were associated in the syllabus. The test was taken when all of the students already had faced statistics as a part of their mathematics course. In educational system of the study, all of the mathematics courses include one block of contents out of five dedicated to statistics and probability from 7 th to 12 th grade. However, only Baaccalaureate students in Science and Social Sciences itineraries have mathematics in their curricula. Hence, only the students that continued their education through these two Baaccalaureate itineraries were included in the survey for the 11th and 12th grades. The number of students continuing their education in statistics diminishes dramatically at the end of the Compulsory Secondary Education, because some students do not continue with any further education, some choose a Vocational Education program and the rest follow a Baccalaureate itinerary in Arts or Humanities. Table 1 shows the sample profile.

Table 1. Profile of students.

\begin{tabular}{ccccc}
\hline Grade (Level) & $\begin{array}{c}\text { N sample/N } \\
\text { Secondary School (\%) }\end{array}$ & Male/Female & $\begin{array}{c}\text { Math Average } \\
\text { Grade }\end{array}$ & $\begin{array}{c}\text { Overall Average } \\
\text { Grade }\end{array}$ \\
\hline 10th grade (CSE) & $62 / 79(78 \%)$ & $36 / 26$ & 6.36 & 6.69 \\
11th grade (B) & $17 / 17(100 \%)$ & $8 / 9$ & 7.75 & 7.8 \\
12th grade (B) & $16 / 17(94 \%)$ & $6 / 10$ & 8.06 & 7.99 \\
Total & $95 / 113(84 \%)$ & $50 / 45$ & 6.92 & 7.14 \\
\hline
\end{tabular}

CSE: Compulsory Secondary Education. B: Baccalaureate. N: Number of students enrolled in mathematics.

Figure 1 graphs the distribution of the overall grades of these students in order to understand the competence level of the students. It can be seen how the grades rise with the time, showing a confidence acquisition in each New Year (Figure 1a). The students of both sexes show a similar performance on the academic studies, the Female group having more dispersion (Figure 1b). This is a particular behaviour of this school, situated in the surrounding area of a Spanish big city. 


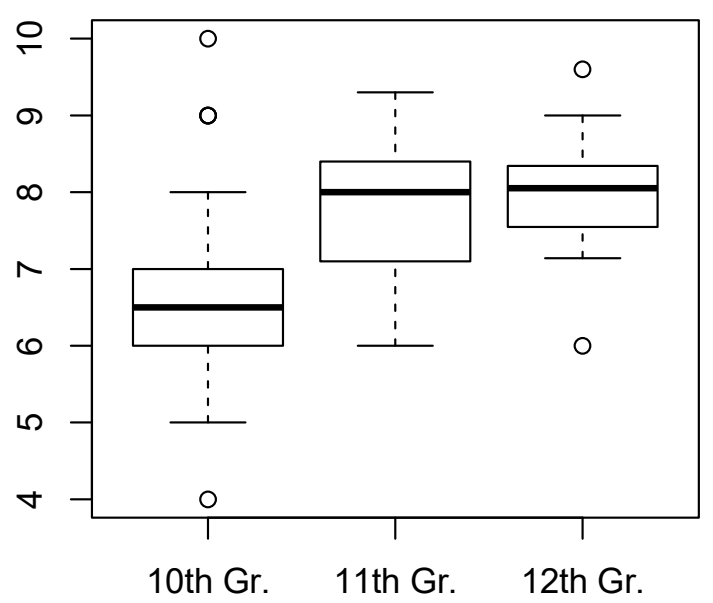

(a)

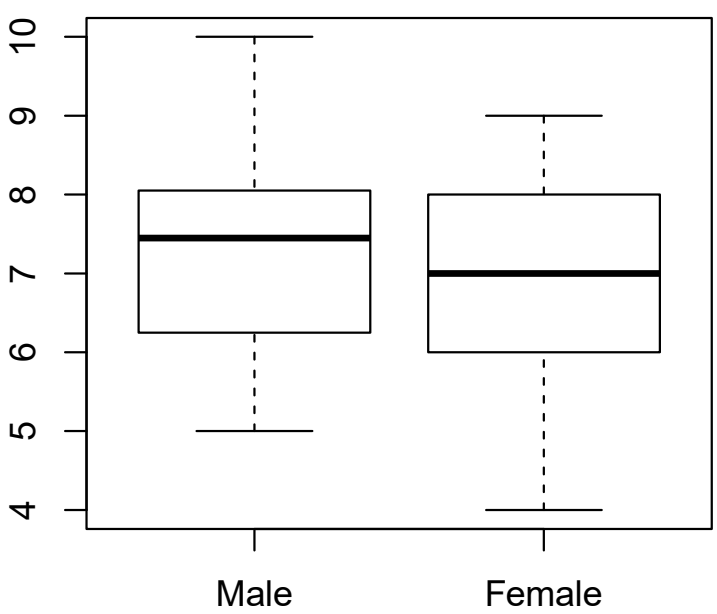

(b)

Figure 1. Distribution of the in the overall average grades obtained by the students that contributed to the study. (a) Grades of the students according the school level. (b) Grades of the students according gender.

MSATS evaluates five attitude components that follow theories and research findings. The questionnaire (see the appendix) contains 25 items to operationalise the five constructs while using a five-point Likert scale $(1=$ "Strongly Disagree", $3=$ "Neither Disagree nor Agree", $5=$ "Strongly Agree"). The attitude components are: usefulness (cognitive dimension), enjoyment, motivation, confidence, and anxiety (affective dimension). These are, respectively: the subjective utility that the knowledge of Statistics represents for the student; the pleasure or enjoyment caused by statistical work; the motivation felt by the student towards the study and use of statistics; the confidence or security that the student has when facing statistics; and the anxiety or fear that the student manifests in front of the subject. Other authors have previously validated these and the measurement instrument $[9,16]$. In our study, we performed a reliability test while using Composite Reliability and, as Table 2 shows, all of the measures exceeded the value of 0.7 [96] for what we considered as valid. We reverse-coded the anxiety and motivation constructs so all of the measures reflected a positive position towards the learning process due to the questionnaire configuration. A higher value on anxiety items thus reflected lower anxiety about learning statistics. The calculated average scores and statistics for the five factors, as indicated by Auzmendi [9], are shown in Table 2. 
Table 2. Constructs of interest.

\begin{tabular}{ccccc}
\hline Construct & Items & Average Value & $\begin{array}{c}\text { Standard } \\
\text { Deviation }\end{array}$ & $\begin{array}{c}\text { Composite } \\
\text { Reliability }\end{array}$ \\
\hline Anxiety (reversed) & $2,3,7,8,12,13,17,18,22$ & 3.46 & 0.602 & 0.825 \\
Enjoyment & $4,9,14,24$ & 2.49 & 0.781 & 0.82 \\
Usefulness & $1,6,15,16,19,21$ & 2.66 & 0.634 & 0.739 \\
Motivation (reversed) & $5,10,25$ & 3.29 & 0.657 & 0.75 \\
Confidence & $11,20,23$ & 3.48 & 0.740 & 0.704 \\
\hline
\end{tabular}

The fsQCA process begins with the calibration of the study measures. The calibration consists of transforming the original measures into calibrated sets. Fuzzy sets vary from 1, indicating full membership, to 0 , corresponding to full non-membership. The values within this range indicate the degree to which each case belongs to a set of the corresponding measure. There are different ways to calibrate constructs that are composed of interval-scale variables. Betti et al. [97] suggest assigning scores to each category through a normalisation process to later calculate the fuzzy indicator weighting the calculated scores with the corresponding latent variable scores that are obtained in a factor analysis. Ragin [89] proposed two different approaches, one that is based on the specification of three anchor points, two thresholds for full membership and full non-membership, and a crossover point that represents the value of the interval-scale variable, where there is maximum ambiguity as to whether a case belongs or not to the target set. The other one is based on regression procedures to estimate degree of set membership. Additionally, among the different options for proceeding with constructs measured with interval-scale variables, previous studies have used the summed values of the items (i.e., Dinh and Thi [98]), the multiplied values of the items (i.e., Palacios et al. [99] or the average values of the items (i.e., Ordanini et al. [100], Palacios et al. [99] or Pappas et al. [101]). In our study, we used the suggested additive measure that was applied by Auzmendi [9] to group the constructs of interest (see Table 2) and use the average value of the suggested items in the measure as the input in our calibration process. We favoured this approach, because, by using latent variable scores, it better captures the overall student-specific attitude due to the reflective nature of the scales for the constructs. It also deals with missing data in the survey properly.

We used the average value of the items as the input measure in the calibration process. Following the direct method [90], we established the cutoff levels for calibration. The three thresholds correspond to full membership, full non-membership, and the crossover point. Several direct methods have been used in previous studies, but most involving a relatively large number of cases for the fsQCA technique use percentiles for this purpose [92,102,103]. For each of the five measures, we used $90 \%$ for full membership, $10 \%$ for full non-membership, and 50\% as the crossover point. The direct calibration method [53] uses estimates of the log of the odds of full membership in a set as an intermediate step to obtain the membership scores. The full membership anchor corresponds to a set membership score of 0.95 and a log odds of 3.0 and, similarly, full non-membership corresponds to a set membership score of 0.05 and log odds of -3.0 . We calculated the deviations of all raw scores from the crossover point and multiply it by the ratio of the log odds associated with cutoff value that we established for full membership or full non-membership, depending on the relative position of each raw score to the crossover point in order to calculate the log odds of each raw score. Finally, we obtain the desired membership score for each case (see 1 ), which is a value that ranges from 0 to 1

$$
\text { degree of membership }=\exp (\log \text { odds }) /(1+\exp (\log \text { odds })) \text {, }
$$

After calibration was complete, we used the fsQCA $3.0[104,105]$ software for the analysis. The fsQCA algorithm produces a truth table with $2 \mathrm{k}$ rows, were $\mathrm{k}$ is the number of conditions that are involved in the prediction of the desired outcome. Thus, the truth table includes all possible combinations of conditions, and each of the observations was classified by the fsQCA algorithm in each of the 16 possible configurations while using the previously calculated calibrated values. Refining the 
truth table to determine the combinations for subsequent analysis is the next step in the process [86]. Ragin [90] has suggested a cutoff level higher than 1 when dealing with medium or large samples and a consistency threshold of 0.8 . Frequency represents the number of observations for each possible combination of conditions, while consistency indicates the proportion of cases in a truth table that displays the outcome [86]. We reduced the truth table and obtained the solutions while using the Quine-McCluskey algorithm with a minimum frequency of two observations and the recommended consistency of 0.80 . Configurations with consistencies higher than the 0.8 were coded as 1 to reflect that they were consistent with sufficient conditions for the outcome. The remaining configurations were coded as 0 .

FsQCA logical minimization can be conducted in different ways, depending on how remainders are used. Remainders are configurations without observed cases [90,106]. If remainders are not considered, the result is often a complex solution, which is normally difficult to interpret. If all of the remainders are considered, even those that are implausible assumptions about how the solutions relate to the outcome, a parsimonious solution, which is easier to interpret, is obtained. A midpoint between these two options is the intermediate solution, which only uses as remainders those cases that are theoretically plausible assumptions about the relationship between the condition and the outcome. We report the intermediate solutions (see Table 3), as they are claimed to be superior to other possible solutions [90].

Table 3. FsQCA results. Low levels of Anxiety towards statistics as outcome.

\begin{tabular}{cccccccc}
\hline & \multicolumn{3}{c}{ Positive Outcome } & \multicolumn{3}{c}{ Negative Outcome } \\
\hline Configuration & 1 & 2 & 3 & 4 & 5 & 6 & 7 \\
Enjoyment & & $\bullet$ & & & & & $\otimes$ \\
Usefulness & $\bullet$ & & $\bullet$ & & & $\otimes$ & \\
Motivation & $\bullet$ & & & $\bullet$ & $\otimes$ & $\otimes$ & \\
Confidence & & $\bullet$ & $\bullet$ & $\bullet$ & $\otimes$ & & \\
Consistency & 0.793 & 0.823 & 0.804 & 0.787 & 0.803 & 0.752 & 0.797 \\
Raw Coverage & 0.511 & 0.527 & 0.513 & 0.466 & 0.536 & 0.469 & 0.506 \\
Unique Coverage & 0.131 & 0.043 & 0.023 & 0.059 & 0.083 & 0.02 & 0.023 \\
Overall Solution consistency & 0.753 & & & & 0.75 & & \\
Overall solution coverage & 0.773 & & & & 0.657 & & \\
\hline
\end{tabular}

Note: Black circles $(\bullet)$ indicate the presence of a condition, and circles with " $x$ " $(\otimes)$ indicate its absence. The blank cells represent conditions that did not matter.

\section{Results}

Table 3 summarizes the intermediate solution. The black circles represent the presence of the causal condition and the white circles with an $x$ represent the absence or negation of causal conditions. The blank cells represent conditions that do not matter. As already indicated, anxiety items were reverse coded before calibration to show a positive relationship to the learning process with the independent variables. Thus, a value closer to 1 in the calibration indicates lower levels of anxiety in the student when dealing with statistics; that is, a positive anxiety outcome in the study indicates a reduction in the levels of student anxiety, which is the desired outcome to improve student performance. Table 3 shows the consistency values over the threshold of 0.75 , as suggested by Ragin [90]. These indicate that the configurations may be considered to be consistent subsets of and sufficient for the outcome [90]. Consistency is similar to significance in statistical models [106].

Regarding the reduction of anxiety, configuration 1 shows that a high perception of usefulness and a high student motivation can lead to lower anxiety, even if the student has no confidence or does not perceive any enjoyment when learning statistics. Configurations 2, 3, and 4 share self-confidence as an ingredient in the recipe for reducing anxiety levels. Specifically, the combination of self-confidence and either the perception enjoyment, usefulness or motivation is a sufficient condition for obtaining a reduction in anxiety towards statistics. This is consistent with self-confidence being at the heart of 
the reduction of anxiety [22]. Note that no single element is, on its own, a sufficient condition for lower levels of anxiety towards statistics.

Solution coverage indicates the extent to which the solution explains a large amount of the reduction in anxiety [107]. This is similar to the variance that is explained in regression models [108]. The solution that is presented in Table 3 explains $77.3 \%$ of low levels of student anxiety towards statistics. Raw coverage accounts for the proportion of low levels of anxiety that each of the configurations explains (i.e., solution 1 covers $51.1 \%$ of the cases with low levels of anxiety). Unique coverage accounts for the proportion of low levels of anxiety that is solely explained by each configuration (i.e., solution 1 covers $13.1 \%$ of the cases with low levels of anxiety that no other solution explains).

We also performed a necessity analysis. A necessary condition is a condition that is present in all of the configurations that lead to the desired outcome. Ragin [107] has suggested a consistency of 0.9 for the necessary conditions. The necessity analysis test revealed that no condition by itself or combined with another condition is necessary to produce the outcome, as all of the consistency levels were lower than 0.9 .

Fiss [86] differentiates between core and peripheral elements, referring to strong or weak causal relationships between the condition and the outcome. Core conditions are those that are present in the intermediate solution and remain in the parsimonious solution, while the peripheral disappear. In our study on the reduction of anxiety, the parsimonious and intermediate solutions are the same and, therefore, all of the combinations of conditions are core elements.

Unlike regression-based models, fsQCA does not assume that dependent and independent variables are symmetric. If the presence of an element is sufficient for the desired outcome to occur, the absence of that element does not necessarily imply automatically the absence of the outcome. Figure 2 illustrates data from the sample plot on the models produced for the positive (a) and the negative outcome (b) and shows that the relationships between the causal combinations in the models and the levels of anxiety are asymmetric. For example, we can see in Figure 2 a that high values in any of the causal combinations of the solutions 1, 2, 3, or 4 (model for positive outcome) are sufficient for low levels of anxiety (high values of the outcome) to occur, but high values of these same solutions are not necessary for low levels of anxiety to occur [92].

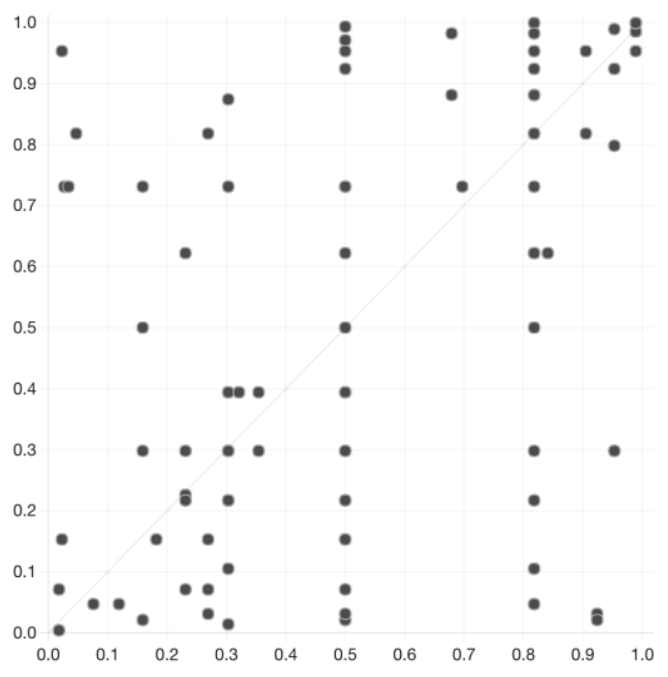

(a) Positive outcome

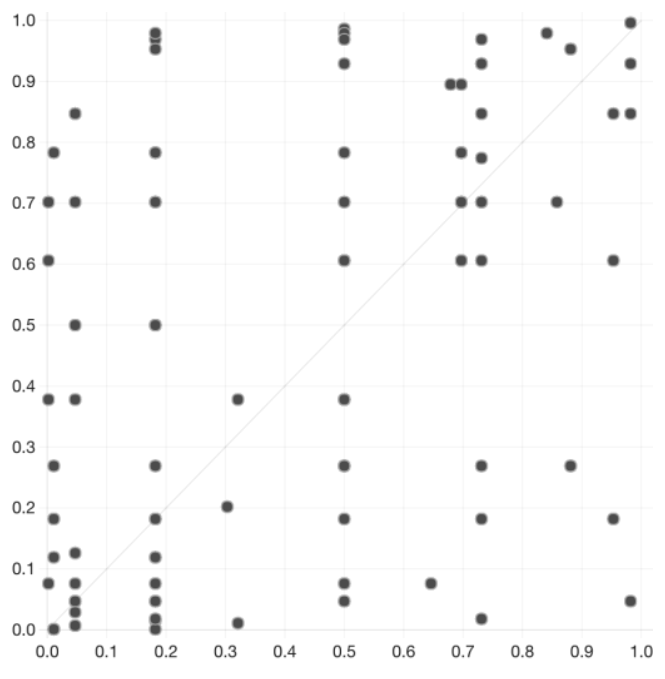

(b) Negative outcome

Figure 2. XY plot of positive (a) and negative (b) outcome calibrated values (level of anxiety) on the $\mathrm{y}$-axis against the causal combinations in the model (attitudes) on the $\mathrm{x}$-axis.

Although we have determined the paths leading to lower levels of anxiety when dealing with statistics, we still do not know which of the paths lead to high levels of anxiety. Solutions 5, 6, and 7 in 
Table 3 display the results for high levels of anxiety. We used the same procedure to obtain the truth table and in the minimization process. The intermediate solution shows a consistency of 0.75 and covers $65.7 \%$ of the cases showing high levels of anxiety. These high levels are present when there is a combination of an absence of motivation and an absence of either self-confidence, the perception of usefulness or enjoyment. We might think that the absence of motivation is a necessary condition for the presence of high levels of anxiety, as the absence of motivation is a common ingredient in any of the recipes that are sufficient to increase the level of anxiety. However, necessity analysis reveals that high levels of anxiety had a consistency lower than 0.9 when there is no or low levels of motivation.

\section{Discussion and Conclusions}

University courses on statistics or other courses in which statistics is used as a method or tool for analysis (e.g., management) have been suffering from low student performance. This situation hinders the appropriate development of the course. Previous research has indicated that knowledge acquired during high school, especially in mathematics, has a strong impact on performance in statistics in higher education [50,63,109]. Attitudes towards the discipline also affect performance [57,58]. Chiesi and Primi [35] found that attitudes towards statistics change during the course. They also found that mathematical competence and negative attitudes at the beginning of the course are associated with high levels of anxiety, which promote low final attitudes towards statistics, which, in turn, yield low performance. This background showed the importance of creating a sense of positive achievement and predisposition to statistics in secondary school. Previous research has uncovered that the relationships between different attitudes towards statistics are complex and that the variety of the results might be due to, for example, the different variables that are involved or the non-linear relationships between the variables [35]. These relationships might not be symmetrical, so the presence or absence of certain variables might affect how they relate and the magnitude or significance of the relationship. Thus, the purpose of this study was to take a different approach to increase the actual knowledge affecting student performance in statistics by studying the levels of anxiety. More specifically, we studied the different recipes or combinations of attitudes leading to lower levels of anxiety and the causal combinations of attitudes that increased these levels.

The main contribution of this paper is to investigate the dependency among students' attitudes towards statistics on their level of anxiety. In the formulation of this research, positive attitudes are hypothesised to decrease the levels of anxiety towards statistics. In this sense, our results were consistent with previous studies, and all of the factors that were involved in the different paths to the desired outcome, low level of anxiety, included positive attitudes towards statistics. However, previous studies reported contradictory results regarding the significant impact of these attitudes. The regression-based methodologies used in the previous research did not effectively account for possible interaction and asymmetry in the relations among the attitudes, which might account for the above-mentioned differences. We used fsQCA to uncover the conditions or combinations of conditions that are sufficient for the expected outcome in order to avoid these limitations and give a complementary view.

We uncovered four different paths that are sufficient to achieve low levels of anxiety. The study revealed that no single attitude is a necessary condition and, instead, we need combinations of at least two positive conditions to reach low anxiety. These results are consistent with previous studies that indicate self-confidence is an important ingredient, which, in combination with other attitudes evaluated, is sufficient for reducing anxiety. However, in situations where self-confidence is low, a combination of motivation and awareness of utility produces the same outcome (low levels of anxiety).

Similarly, all of the combinations leading to high levels of anxiety were formed with a combination of negative outcomes. All of these sufficient causal combinations included low levels of motivation, which indicates the crucial role of motivation to avoid high levels of anxiety. However, motivation did not pass the necessity analysis; that is, all of the students with high levels of anxiety had low levels of motivation, but not all students with low levels of motivation showed high levels of anxiety. 
In practice, the results of this study help us to understand which combinations of attitudes are sufficient for students to reduce levels of anxiety or to avoid high levels of anxiety when facing statistics and, consequently, to improve students' performance with statistics. These combinational patterns can help focus educators' actions towards those attitudes that produce a positive outcome. For example, we might want to design applied activities that show the students the usefulness of statistics in the real world and then gradually increase the difficulty to build self-confidence and consequently reduce the levels of anxiety. Similarly, designing fun activities that are related to statistics is not going to reduce the level of anxiety, unless those activities also build on students' self-confidence. On the contrary, low motivation is a common factor to all of the paths leading to high levels of anxiety. Educators might want to use strategies to avoid decreasing students' motivation or at least to avoid demotivating them.

Our study has some limitations. First, we tested students' attitudes towards statistics in a single secondary school. Although this issue allows for us to guarantee the homogeneity of students' educational environment (e.g., the social level, the educators to whom they have been exposed, or the previous educational origin), it certainly limits the generalizability of our conclusions. This study was also conducted while examining secondary school students who had limited exposure to statistics within a mathematics course, while, in higher education, there is dedicated statistics courses. A longer exposure to statistics and the experience acquired by students throughout secondary school and in the beginning of university courses might therefore change the attitudes or the capability of students to control those attitudes. In addition, there might be other factors or attitudes, such as the teaching capability of educators or the learning approach, which might also affect or moderate the relationships of the studied attitudes on the levels of anxiety about statistics. An examination of these other factors or moderators is advisable for future research.

Author Contributions: Conceptualization, Á.P.-S., Ó.T. and J.C.G.-D.; data acquisition Ó.T., validation, methodology and formal analysis, Á.P.-S. and M.S.-O.; writing-original draft preparation, Á.P.-S. and Ó.T.; writing-review and editing, Á.P.-S., M.S.-O. and J.C.G.-D. All authors have read and agreed to the published version of the manuscript.

Funding: This research received no external funding.

Conflicts of Interest: The authors declare no conflict of interest.

\section{Appendix A}

The survey comprised the following questions

Age:

Gender: Male Female

Grade: 10th 11th 12th

Average average in mathematics:

Overall average grade:

1 I consider statistics as a very necessary subject in my studies.

2 I'm pretty bad at statistics.

3 Studying or working with statistics doesn't scare me at all.

$4 \quad$ Using statistics is fun.

5 Statistics is too theoretical for me to be of any use.

6 I want to have a deeper understanding of Statistics.

$7 \quad$ Statistics is one of the subjects that I fear the most.

8 I have confidence in myself when I face a statistical problem.

$9 \quad$ I enjoy talking to others about statistics.

10 Statistics can be useful for those who decide to pursue a science career, but not for other students.

11 Having a good knowledge of statistics will increase my job possibilities. 
12

When I face a statistical problem I feel unable to think clearly. I am calm when I face a problem of statistics. Statistics is nice and challenging for me. I hope to have little use of statistics in my professional life.

I consider that there are other matters more important than statistics for my future profession.

Working with statistics makes me feel nervous.

I don't get upset when I have to work on statistics problems.

I would like to have an occupation in which I have to use statistics.

It gives me great satisfaction to solve statistical problems.

For my professional future, statistics is one of the most important subjects I have to study. Statistics makes me feel uncomfortable and nervous. If I put my mind to it, I think I can master statistics. If I had the opportunity, I would enroll in more statistics courses than are required. The things taught in statistics classes are very uninteresting

\section{References}

1. Gal, I.; Ginsburg, L. The Role of Beliefs and Attitudes in Learning Statistics: Towards an Assessment Framework. J. Stat. Educ. 1994, 2, 2. [CrossRef]

2. Cashin, S.E.; Elmore, P.B. The survey of attitudes toward statistics scale: A construct validity study. Educ. Psychol. Meas. 2005, 65, 509-524. [CrossRef]

3. Garfield, J.; Ben-Zvi, D. How students learn statistics revisited: A current review of research on teaching and learning statistics. Int. Stat. Rev. 2007, 75, 372-396. [CrossRef]

4. Schau, C.; Millar, M.; Petocz, P. Research On Attitudes Towards Statistics. Stat. Educ. Res. J. 2012, 11, $2-5$.

5. Chiesi, F.; Primi, C. Assessing statistics attitudes among college students: Psychometric properties of the Italian version of the Survey of Attitudes toward Statistics (SATS). Learn. Individ. Differ. 2009, 19, 309-313. [CrossRef]

6. Gal, I.; Ginsburg, L.; Schau, C. Monitoring attitudes and beliefs in statistics education. Assess. Chall. Stat. Educ. 1997, 12, 37-51.

7. Biens, B. Teaching the Relevance of Statistics Through Consumer-Oriented Research. Teach. Psychol. 1985, 12, 168-169. [CrossRef]

8. Estrada, A. Tesis Doctoral Analisis De Las Actitudes Y Conocimientos. Analysis of Attitudes and Knowledge. Ph.D. Thesis, Universitat Autònoma de Barcelona, Barcelona, Spain, 2003.

9. Auzmendi Escribano, E. Las Actitudes Hacia la Matemática-Estadística en las Enseñanzas Media y Universitaria [Attitudes towards Statistical Mathematics in Secondary and University Education]; Mensajero, D.L.: Bilbao, Spain, 1992; ISBN 84-271-1768-X.

10. Carmona Márquez, J. Una revisión de las evidencias de fiabilidad y validez de los cuestionarios de actitudes $\mathrm{y}$ ansiedad hacia la estadística [A review of the evidence of reliability and validity of the attitudes and anxiety questionnaires towards statistics]. Stat. Educ. Res. J. 2004, 3, 5-28.

11. Rojo Robas, V.; Madariaga, J.M.; Villarroel, J.D. Secondary Education Students' Beliefs about Mathematics and Their Repercussions on Motivation. Mathematics 2020, 8, 368. [CrossRef]

12. Roberts, D.M.; Bilderback, E.W. Reliability and Validity of a Statistics Attitude Survey. Educ. Psychol. Meas. 1980, 40, 235-238. [CrossRef]

13. Wise, S.L. The development and validation of a scale measuring attitudes toward statistics. Educ. Psychol. Meas. 1985, 45, 401-405. [CrossRef]

14. Schau, C.; Stevens, J.; Dauphinee, T.L.; Vecchio, A. Del The development and validation of the survey of antitudes toward statistics. Educ. Psychol. Meas. 1995, 55, 868-875. [CrossRef] 
15. Bayot-Mestre, A.; Mondéjar-Jiménez, J.; Mondéjar-Jiménez, J.A.; Monsalve-Serrano, F.; Vargas-Vargas, M. The Difficulties of Learning Concepts in the Social Sciences. In Studies in Teacher Education: Psichopedagogy; Misztal, M., Trawiński, M., Eds.; Wydawnictwo Naukowe AP: Krakow, PL, USA, 2005; pp. 242-258. ISBN 83-7271-355-1.

16. Fernández Cézar, R.; Solano Pinto, N.; Rizzo, K.; Gomezescobar Camino, A.; Iglesias, L.M.; Espinosa, A. Las actitudes hacia las matemáticas en estudiantes y maestros de educación infantil y primaria: Revisión de la adecuación de una escala para su medida [Attitudes towards mathematics in students and teachers of early childhood and primary education: Review. Rev. Iberoam. Ciencia, Tecnol. y Soc. CTS 2016, 11, 227-238.

17. Gil Flores, J. Actitudes hacia la estadística. Incidencia de las variables sexo y formación previa [Attitudes towards statistics. Incidence of the variables sex and previous training]. Rev. Española Pedagog. 1999, 57, 567-589.

18. Schau, C.; Dauphinee, T.L.; Del Vecchio, A.; Stevens, J.J. Survey of attitudes toward statistics. Comm. Rev. 2003, 250, 8984901.

19. Eccles, J. Expectancies, values and academic behaviors. In Achievement and Achievement Motives: Psychological and Sociological Approaches; Spence, J.T., Ed.; W.H. Freeman: San Francisco, CA, USA, 1983; pp. 75-146. ISBN 9780716713968.

20. Bandura, A. Self-Efficacy: The Exercise of Control; W. H. Freeman: New York, NY, USA, 1999; pp. 158-166. ISBN 978-0-7167-2850-4.

21. Roberts, D.M.; Saxe, J.E. Validity of a Statistics Attitude Survey: A Follow-Up Study. Educ. Psychol. Meas. 1982, 42, 907-912. [CrossRef]

22. Zeidner, M. Statistics and mathematics anxiety in social science students: Some interesting parallels. Br. J. Educ. Psychol. 1991, 61, 319-328. [CrossRef]

23. Baloğlu, M. Individual differences in statistics anxiety among college students. Pers. Individ. Dif. 2003, 34, 855-865. [CrossRef]

24. Schram, C.M. A Meta-Analysis of Gender Differences in Applied Statistics Achievement. J. Educ. Behav. Stat. 1996, 21, 55-70. [CrossRef]

25. Clute, P.S. Mathematics Anxiety, Instructional Method, and Achievement in a Survey Course in College Mathematics. J. Res. Math. Educ. 1984, 15, 50-58. [CrossRef]

26. Pulido, J.E. Enseñanza de la estadística a partir de la actitud del alumno. Laurus 2009, 15, 42-70.

27. Aparicio, A.; Bazán, J. Actitud y Rendimiento en Estadística en Profesores Peruanos [Attitude and Performance in Statistics in Peruvian Teachers]. In Proceedings of the Acta Latinoamericana de Matemática Educativa; Martínez, G., Ed.; Comité Latinoamericano de Matemática Educativa A. C.: México DF, Mexico, 2006; pp. 644-650.

28. Mondéjar Jiménez, J.; Vargas Vargas, M.; Mondéjar Jiménez, J. Impacto del uso del e-learning en las actitudes hacia la estadística [Impact of the use of e-learning on attitudes towards statistics]. Relatec Rev. Latinoam. Tecnol. Educ. 2007, 6, 41-48.

29. Blanco, Á.B. Una revisión crítica de la investigación sobre las actitudes de los estudiantes universitarios hacia la Estadística [A critical review of the research on the attitudes of university students towards Statistics]. Rev. Complut. Educ. 2008, 19, 311-330.

30. Estrada, A. Instrumentos de Medición de Actitudes Hacia la Estadística: La Escala EAEE para Profesores [Instruments for Measuring Attitudes towards Statistics: The EAEE scale for teachers]. In Proceedings of the Investigación en Educación Matemática. Comunicaciones de los Grupos de Investigación de la SEIEM; Edicions de la Universitat de Lleida: Lleida, Spain, 2011; pp. 233-251.

31. Froelich, A.G.; Stephenson, W.R.; Duckworth, W.M. Assessment of Materials for Engaging Students in Statistical Discovery. J. Stat. Educ. 2008, 16, 2. [CrossRef]

32. Onwuegbuzie, A.J.; Daley, C.E. Perfectionism and statistics anxiety. Pers. Individ. Dif. 1999, 26, 1089-1102. [CrossRef]

33. Benson, J. Structural Components of Statistical Test Anxiety in Adults. J. Exp. Educ. 1989, 57, $247-261$. [CrossRef]

34. Carmona, J.; Martínez, R.J.; Sánchez, M. Mathematical Background and Attitudes toward Statistics in a Sample of Spanish College Students. Psychol. Rep. 2005, 97, 53-62. [CrossRef]

35. Chiesi, F.; Primi, C. Cognitive and non-cognitive factors related to students' statistics achievement. Stat. Educ. Res. J. 2010, 9, 6-26. 
36. Macher, D.; Paechter, M.; Papousek, I.; Ruggeri, K. Statistics anxiety, trait anxiety, learning behavior, and academic performance. Eur. J. Psychol. Educ. 2012, 27, 483-498. [CrossRef]

37. Musch, J.; Broder, A. Test anxiety versus academic skills: A comparison of two alternative models for predicting performance in a statistics exam. Br. J. Educ. Psychol. 1999, 69, 105-116. [CrossRef]

38. Onwuegbuzie, A.J.; Seaman, M.A. The Effect of Time Constraints and Statistics Test Anxiety on Test Performance in a Statistics Course. J. Exp. Educ. 1995, 63, 115-124. [CrossRef]

39. Tremblay, P.F.; Gardner, R.C.; Heipel, G. A model of the relationships among measures of affect, aptitude and performance in introductory statistics. Can. J. Behav. Sci. 2000, 32, 40. [CrossRef]

40. Fitzgerald, S.M.; Jurs, S.J.; Hudson, L.M. A model predicting statistics achievement among graduate students. Coll. Stud. J. 1996, 30, 361-366.

41. Ferrando, P.J.; Varea, M.D.; Lorenzo, U. Evaluación psicométrica del cuestionario de ansiedad y rendimiento (CAR) en una muestra de escolares [Psychometric evaluation of the anxiety and performance questionnaire (APQ) in a sample of schoolchildren]. Psicothema 1999, 11, 225-236.

42. Hardy, L.; Hagtvet, K.A. Anxiety and performance: Measurement and modelling issues. Anxiety Stress. Coping 1996, 9, v-viii. [CrossRef]

43. Birenbaum, M.; Nasser, F. On the Relationship between Test Anxiety and Test Performance. Meas. Eval. Couns. Dev. 1994, 27, 293-301.

44. King, N.J.; Ollendick, T.H.; Gullone, E. Test anxiety in children and adolescents. Aust. Psychol. 1991, 26, 25-32. [CrossRef]

45. Seipp, B. Anxiety and academic performance: A meta-analysis of findings. Anxiety Res. 1991, 4, $27-41$. [CrossRef]

46. Sesé, A.; Jiménez, R.; Montaño, J.J.; Palmer, A. Can Attitudes Toward Statistics and Statistics Anxiety Explain Students' Performance? Rev. Psicodidact. 2015, 20, 285-304. [CrossRef]

47. Mondéjar-Jiménez, J.; Vargas-Vargas, M. Determinant factors of attitude towards quantitative subjects: Differences between sexes. Teach. Teach. Educ. 2010, 26, 688-693. [CrossRef]

48. Nasser, F.M. Structural Model of the Effects of Cognitive and Affective Factors on the Achievement of Arabic-Speaking Pre-service Teachers in Introductory Statistics. J. Stat. Educ. 2004, 12. [CrossRef]

49. Onwuegbuzie, A.J. Modeling Statistics Achievement among Graduate Students. Educ. Psychol. Meas. 2003, 63, 1020-1038. [CrossRef]

50. Lalonde, R.N.; Gardner, R.C. Statistics as a second language? A model for predicting performance in psychology students. Can. J. Behav. Sci. Can. Sci. Comport. 1993, 25, 108. [CrossRef]

51. Budé, L.; Van De Wiel, M.W.J.; Imbos, T.; Candel, M.J.J.M.; Broers, N.J.; Berger, M.P.F. Students' achievements in a statistics course in relation to motivational aspects and study behaviour. Stat. Educ. Res. J. 2007, 6, 5-21.

52. Onwuegbuzie, A.J. Statistics anxiety: A function of learning style? Res. Sch. 1998, 5, 43-52.

53. Onwuegbuzie, A.J. Statistics Anxiety and the Role of Self-Perceptions. J. Educ. Res. 2000, 93, 323-330. [CrossRef]

54. Katz, B.M.; Tomazic, T.J. Changing students' attitudes toward statistics through a nonquantitative approach. Psychol. Rep. 1988, 62, 658. [CrossRef]

55. Vanhoof, S.; Castro Sotos, A.E.; Onghena, P.; Verschaffel, L.; Van Dooren, W.; Van den Noortgate, W. Attitudes toward Statistics and Their Relationship with Short- and Long-Term Exam Results. J. Stat. Educ. 2006, 14. [CrossRef]

56. Evans, B. Student Attitudes, Conceptions, and Achievement in Introductory Undergraduate College Statistics. Math. Educ. 2015, 17, 20-24.

57. Sorge, C.; Schau, C. Impact of Engineering Students' Attitudes on Achievement in Statistics: A Structural Model. In Proceedings of the Annual Meeting of the American Educational Research, New Orleans, LA, USA, 1-5 April 2002; pp. 1-21.

58. Wisenbaker, J.M.; Scott, J.S.; Nasser, F. Structural Equation Models Relating Attitudes about and Achievement in Introductory Statistics Courses: A Comparison of Results from the US and Israel. In Proceedings of the 9th International Congress on Mathematics Education, Tokyo, Japan, 1-4 August 2000; pp. 1-8.

59. López, C.R.S. Validación y análisis ipsativo de la escala de actitudes hacia la estadística (EAE) [Validation and ipsative analysis of the scale of attitudes towards statistics (ATS)]. Análisis y Modif. Conduct. 1996, 22, 799-819.

60. Bandalos, D.L.; Finney, S.J.; Geske, J.A. A model of statistics performance based on achievement goal theory. J. Educ. Psychol. 2003, 95, 604. [CrossRef] 
61. Onwuegbuzie, A.J.; Bailey, P.; Daley, C.E. The role of foreign language anxiety and students' expectations in foreign language learning. Res. Sch. 2002, 9, 33-50.

62. Bandalos, D.L.; Yates, K.; Thorndike-Christ, T. Effects of math self-concept, perceived self-efficacy, and attributions for failure and success on test anxiety. J. Educ. Psychol. 1995, 87, 611-623. [CrossRef]

63. Schutz, P.A.; Drogosz, L.M.; White, V.E.; Distefano, C. Prior knowledge, attitude, and strategy use in an introduction to statistics course. Learn. Individ. Differ. 1998, 10, 291-308. [CrossRef]

64. da Silva, C.B.; Cazorla, I.M.; Brito, M.R.F. de Concepções e Atitudes em Relação à Estatística [Conceptions and Attitudes towards Statistics]. In Proceedings of the Comunicación presentada a la Conferência Internacional Experiências e Expectativas do Ensino da Estatística: Desafios para o Século XXI, Florianópolis, Brazil, 20-23 September 1999.

65. Vigil-Colet, A.; Lorenzo-Seva, U.; Condon, L. Development and validation of the statistical anxiety scale. Psicothema 2008, 20, 174-180.

66. Usher, E.L.; Pajares, F. Sources of Self-Efficacy in School: Critical Review of the Literature and Future Directions. Rev. Educ. Res. 2008, 78, 751-796. [CrossRef]

67. Comas, C.; Martins, J.A.; Comas, C.; Martins, J.A.; Nascimento, M.M.; Estrada, A. Estudio de las Actitudes hacia la Estadística en Estudiantes de Psicología [Study of attitudes towards statistics in psychology students]. Bolema Braz. 2017, 31, 479-496. [CrossRef]

68. Ramirez, C.; Schau, C.; Emmioğlu, E. The importance of attitudes in statistics education. Stat. Educ. Res. J. 2012, 11, 57-71.

69. Daley, C.E.; Onwuegbuzie, A.J. The role of multiple intelligences in statistics anxiety. In Proceedings of the Anual Meting of the Mid-South Educational Research Association; U.S. Department of Education: Memphis, TN, USA, 1997; Volume 3, pp. 1-12.

70. Walsh, J.J.; Ugumba-Agwunobi, G. Individual differences in statistics anxiety: The roles of perfectionism, procrastination and trait anxiety. Pers. Individ. Dif. 2002, 33, 239-251. [CrossRef]

71. Vera, O.; Díaz, C. Dificultades de estudiantes de psicología en relación al contraste de hipótesis [Difficulties of psychology students in relation to hypothesis testing]. Probab. Condicionada 2013, 2, 197-203.

72. Gómez Chacón, I.M. Matemática Emocional [Texto impreso]: Los afectos en el Aprendizaje Matemático; Narcea Ediciones SL: Madrid, Spain, 2000; ISBN 84-277-1336-3.

73. Ribes Giner, G.; Perelló Marín, M.R.; Pantoja Díaz, O. Literature of the key variables of the co-creation process in higher education institutions. Tec. Empres. 2017, 11, 41-53. [CrossRef]

74. Müller-Merbach, H. Knowledge management: A program for education and leadership. Knowl. Manag. Res. Pract. 2008, 6, 350-356. [CrossRef]

75. Trull-Domínguez, O.; Peiró-Signes, Á.; Segarra-Oña, M. Aprendizaje de Herramientas de SPC Mediante Actividades Experienciales y Utilizando Alubias [Learning SPC tools through Experiential Activities and Using Beans]. In Proceedings of the Book of abstracts CIVINEDU 2018: 2nd International Virtual Conference on Educational Research and Innovation, Eindhoven, The Netherlands, 24-25 October 2018; p. 129.

76. Peiro-Signes, A.; Segarra-Ona, M.V.; Trull-Dominguez, O.; De-Miguel-Molina, B. Bean Bags: An Experiential Learning Activity for Quality Control. In Proceedings of the EDULEARN17 Conference, Barcelona, Spain, 3-5 July 2017; IATED: Barcelona, Spain, 2017; pp. 8216-8221.

77. Peiró Signes, A.; Trull Domínguez, Ó.; Segarra Oña, M.d.V. Desarrollo de una Actividad Experiencial para la Enseñanza de Estadística [Development of an Experiential Activity for the Teaching of Statistics]. In Proceedings of the In-Red 2017. III Congreso Nacional de Innovación Educativa y de Docencia en Red, Valencia, Spain, 13-14 July 2017; Editorial Universitat Politècnica de València: Valencia, Spain, 2017; pp. 282-288.

78. Trull Dominguez, O.; Peiro-Signes, A.; Segarra Oña, M.; de Miguel Molina, M. Learning design of experiments with catapults. In Proceedings of the 10th annual International Conference of Education, Research and Innovation, Seville, Spain, 16-18 November 2017; IATED: Seville, Spain, 2017; pp. 1920-1926.

79. Trull Dominguez, O.; Peiro-Signes, A.; Segarra-Oña, M.; De-Miguel-Molina, M. Enhancing learning of the application of statistical concepts through experiences. In Proceedings of the 10th annual International Conference of Education, Research and Innovation; IATED: Seville, Spain, 2017; pp. 2905-2911.

80. Trull-Dominguez, O.; Peiro-Signes, A.; Segarra-Oña, M. Experiential Learning Activity: Outdoor Passage to Learn Statistics. In Proceedings of the ICERI Proceedings, Seville, Spain, 12-14 November 2018; IATED: Seville, Spain, 2018; pp. 7374-7380. 
81. Carnell, L.J. The effect of a student-designed data collection project on attitudes toward statistics. J. Stat. Educ. 2008, 16. [CrossRef]

82. Slootmaeckers, K.; Kerremans, B.; Adriaensen, J. Too Afraid to learn: Attitudes towards statistics as a barrier to learning statistics and to acquiring quantitative skills. Politics 2014, 34, 191-200. [CrossRef]

83. Anastasiadou, S. Affective reactions and attitudes of the last class of greek high school students towards statistics. In Proceedings of the CERME IV, European Research in Mathematics Education, Girona, Spain, 17-21 Februbry 2005; IQS FUNDEMI Bussiness Institute: Girona, Spain, 2005.

84. Elmore, P.B.; Vasu, E.S. A Model of Statistics Achievement Using Spatial Ability, Feminist Attitudes and Mathematics-Related Variables as Predictors. Educ. Psychol. Meas. 1986, 46, 215-222. [CrossRef]

85. Zimmer, J.C.; Fuller, D.K. Factors Affecting Undergraduate Performance in Statistics: A Review of Literature. In Proceedings of the Paper presented at the Annual Meeting of the Mid-South Educational Research Association; ERIC: Tuscaloosa, AL, USA, 1996.

86. Fiss, P.C. Building Better Causal Theories: A Fuzzy Set Approach to Typologies in Organization Research. Acad. Manag. J. 2011, 54, 393-420. [CrossRef]

87. Hotchkiss, E.S.; Strömberg, P.; Smith, D.C. Private Equity and the Resolution of Financial Distress. In Proceedings of the AFA 2012 Chicago Meetings, Chicago, IL, USA, 6-8 January 2014; PaperAFA: Chicago, IL, USA, 2014.

88. Fiss, P.C. A set-theoretic approach to organizational configurations. Acad. Manag. Rev. 2007, 32, 1180-1198. [CrossRef]

89. Braumoeller, B.F. Hypothesis Testing and Multiplicative Interaction Terms. Int. Organ. 2004, 58, 807-820. [CrossRef]

90. Rihoux, B.; Ragin, C.C. Configurational Comparative Methods: Qualitative Comparative Analysis (QCA) and Related Techniques; Sage Publications: New York, NY, USA, 2008; Volume 51, ISBN 1452210314.

91. Rihoux, B. Qualitative Comparative Analysis (QCA) and Related Systematic Comparative Methods: Recent Advances and Remaining Challenges for Social Science Research. Int. Sociol. 2006, 21, 679-706. [CrossRef]

92. Woodside, A.G. Moving beyond multiple regression analysis to algorithms: Calling for adoption of a paradigm shift from symmetric to asymmetric thinking in data analysis and crafting theory. J. Bus. Res. 2013, 66, 463-472. [CrossRef]

93. Ragin, C.C. Fuzzy-Set Social Science; University of Chicago Press: Chicago, IL, USA, 2000; ISBN 0226702774.

94. Emmenegger, P.; Schraff, D.; Walter, A. QCA, the Truth Table Analysis and Large-N Survey Data: The Benefits of Calibration and the Importance of Robustness Tests. In Proceedings of the 2nd international QCA Expert Workshop, Zurich, Switzerland, 5-7 November 2014.

95. Liu, Y.; Mezei, J.; Kostakos, V.; Li, H. Applying configurational analysis to IS behavioural research: A methodological alternative for modelling combinatorial complexities. Inf. Syst. J. 2017, 27, 59-89. [CrossRef]

96. Nunnally, J.C.; Bernstein, I.H. Psychometric Theory, 3rd ed.; McGraw-Hill: New York, NY, USA, 1994; ISBN 0-07-047849-X.

97. Betti, G.; D'Agostino, A.; Neri, L. Educational Mismatch of Graduates: A Multidimensional and Fuzzy Indicator. Soc. Indic. Res. 2011, 103, 465-480. [CrossRef]

98. Tho, N.D.; Trang, N.T.M. Can knowledge be transferred from business schools to business organizations through in-service training students? SEM and fsQCA findings. J. Bus. Res. 2015, 68, 1332-1340. [CrossRef]

99. Palacios-Marqués, D.; Roig-Dobón, S.; Comeig, I. Background factors to innovation performance: Results of an empirical study using fsQCA methodology. Qual. Quant. 2017, 51, 1939-1953. [CrossRef]

100. Ordanini, A.; Parasuraman, A.; Rubera, G. When the Recipe Is More Important Than the Ingredients: A Qualitative Comparative Analysis (QCA) of Service Innovation Configurations. J. Serv. Res. 2013, 17, 134-149. [CrossRef]

101. Pappas, I.O.; Kourouthanassis, P.E.; Giannakos, M.N.; Chrissikopoulos, V. Explaining online shopping behavior with fsQCA: The role of cognitive and affective perceptions. J. Bus. Res. 2016, 69, 794-803. [CrossRef]

102. Dul, J. Identifying single necessary conditions with NCA and fsQCA. J. Bus. Res. 2016, 69, 1516-1523. [CrossRef] 
103. Beynon, M.J.; Jones, P.; Pickernell, D. Country-based comparison analysis using fsQCA investigating entrepreneurial attitudes and activity. J. Bus. Res. 2016, 69, 1271-1276. [CrossRef]

104. Ragin, C.C.; Davey, S. Fuzzy-Set/Qualitative Comparative Analysis 3.0; Department of Sociology, University of California: Irvine, CA, USA, 2016.

105. Ragin, C.C. User's Guide to Fuzzy-Set/Qualitative Comparative Analysis 3.0; Department of Sociology, University of California: Irvine, CA, USA, 2018.

106. Schneider, C.Q.; Wagemann, C. Standards of Good Practice in Qualitative Comparative Analysis (QCA) and Fuzzy-Sets. Comp. Sociol. 2010, 9, 397-418. [CrossRef]

107. Ragin, C.C. Redesigning Social Inquiry: Fuzzy Sets and Beyond; University of Chicago Press: Chicago, IL, USA, 2009; ISBN 0226702790.

108. Ragin, C.C. Set Relations in Social Research: Evaluating Their Consistency and Coverage. Polit. Anal. 2006, 14, 291-310. [CrossRef]

109. Harlow, L.L.; Burkholder, G.J.; Morrow, J.A. Evaluating Attitudes, Skill, and Performance in a Learning-Enhanced Quantitative Methods Course: A Structural Modeling Approach. Struct. Equ. Model. A Multidiscip. J. 2002, 9, 413-430. [CrossRef]

(C) 2020 by the authors. Licensee MDPI, Basel, Switzerland. This article is an open access article distributed under the terms and conditions of the Creative Commons Attribution (CC BY) license (http://creativecommons.org/licenses/by/4.0/). 